\title{
The Primary Structure of Porcine Pancreatic Elastase
}

\author{
THE $N$-TERMINUS AND DISULPHIDE BRIDGES
}

\author{
BY J. R. BROWN, DOROTHY L. KAUFFMAN AND B. S. HARTLEY \\ Medical Research Council Laboratory of Molecular Biology, Cambridge
}

(Received 10 October 1966)

\begin{abstract}
1. The amino acid composition and $N$-terminal groups of purified elastase show that it is a single peptide chain of 234 residues. 2. The $N$-terminal sequence is Val-Val-Gly-Gly-Thr-Glu-. 3. The sequences around the four disulphide bridges were determined by using a 'diagonal' electrophoretic technique. 4. These four bridges are homologous with the four common to bovine trypsin and chymotrypsin. 5 . Out of 83 residues of the elastase sequence so far determined, 43 are homologous with similar regions of trypsin and chymotrypsin. 6. The evolutionary ancestry of these enzymes is discussed.
\end{abstract}

Naughton \& Sanger (1961) showed that porcine pancreatic elastase differs in specificity from the bovine pancreatic endopeptidases, trypsin and chymotrypsin, but that like them it was inhibited by di-isopropyl phosphorofluoridate. That it was indeed a similar 'serine' proteinase was shown by the identity of sequence around the unique serine residue which reacts with di-isopropyl phosphorofluoridate in all three enzymes (Hartley, Naughton \& Sanger, 1959; Naughton, Sanger, Hartley \& Shaw, 1960). Elastase also contains a disulphidebridged 'histidine-loop' sequence similar to that in trypsin and chymotrypsin (Smillie \& Hartley, 1964). Hence we may ask what further resemblence exists between these three different pancreatic proteinases.

The diagonal electrophoretic technique of Brown \& Hartley $(1963,1966)$ has proved to be a very convenient method for determining amino acid sequences around disulphide bridges in proteins. It revealed that four disulphide bridges are homologous in bovine trypsin (Kauffman, 1965), chymotrypsin A (Brown \& Hartley, 1963) and chymotrypsin B (Smillie \& Hartley, 1965), both in amino acid sequence and position along the peptide chain. We therefore used this technique to determine the sequence around the disulphide bridges of porcine elastase. The following experiments, which have been briefly discussed elsewhere (Hartley, Brown, Kauffman \& Smillie, 1965), indicate a surprising degree of homology between the three different enzymes.

\section{MATERIALS}

Porcine elastase. This was prepared either from Pancreatin (Koch-Light Laboratories Ltd., Colnbrook, Bucks.) or Trypsin 1-300 (Nutritional Biochemicals Corp., Cleveland, Ohio, U.S.A.) by the method of Lewis, Williams \& Brink
(1956) as modified by Smillie \& Hartley (1966). For some experiments the starting material was Crystalline Elastase (Worthington Biochemical Corp., Freehold, N.J., U.S.A.), which contains some $20-50 \%$ of the pure enzyme. Elastase activities were assayed by the Congo Red-dyed elastin technique of Naughton \& Sanger (1961), and expressed as the reciprocal of the time (min.) taken to digest half of the elastin (5 mg.).

Other enzymes. Bovine trypsin, $\alpha$-chymotrypsin and carboxypeptidase $\mathbf{A}$ and porcine pepsin and papain were crystalline products from Worthington Biochemical Corp.; crystalline subtilisin B was from Novo Terapeutisk Laboratorium, Copenhagen, Denmark, and Pronase-P from California Corp. for Biochemical Research, Los Angeles, Calif., U.S.A.

\section{METHODS}

Peptic digestion of elastase. Elastase (200 mg.) and pepsin (20 mg.) were dissolved in $20 \mathrm{ml}$. of $5 \%(\mathrm{v} / \mathrm{v})$ formic acid and incubated at $37^{\circ}$ for $16 \mathrm{hr}$.

Diagonal paper electrophoresis for cystine peptides. Groups of cysteic acid peptides were isolated from the peptic digest by the method of Brown \& Hartley (1966).

Enzymic digestion of peptides. Peptides were digested with trypsin, chymotrypsin, Pronase, subtilisin or carboxy. peptidase in $0.2 \mathrm{M}-N$-ethylmorpholine-acetate buffer, pH 8.0, or $0.5 \% \mathrm{NH}_{4} \mathrm{HCO}_{3}, \mathrm{pH} 8.0$, as described by Smillie \& Hartley (1966). Unless otherwise stated, digestions were at room temperature overnight with approx. 1 mM-peptide and a 1:50 enzyme/substrate molar ratio. Papain digests were carried out in $1 \mathrm{~m}$-pyridine-acetate buffer, $\mathrm{pH} 6.5$, containing $0.1 \mathrm{M}$-mercaptoethanol. Partial acid hydrolysis of peptides was carried out in $5 \cdot 7 \mathrm{~N}-\mathrm{HCl}$ at $37^{\circ}$ for $52 \mathrm{hr}$.

Amino acid analysis. Peptides were hydrolysed in $5 \cdot 7 \mathrm{~N}$ $\mathrm{HCl}$ in sealed evacuated tubes for $16 \mathrm{hr}$. at $105^{\circ}$. For protein analyses identical samples were hydrolysed for 16, 40 and $72 \mathrm{hr}$. to allow corrections for destruction of serine and threonine and incomplete hydrolysis of valyl and isoleucyl peptides. A Beckman Spinco model 120 amino acid analyser was generally used, with the accelerated-flow system of 
Spackman (1963), or an apparatus constructed in this Laboratory on essentially similar principles.

Sequence determinations. The 'dansyl'-Edman technique (Gray \& Hartley, 1963a,b) as described by Smillie \& Hartley (1966) was the main method of sequential analysis of peptides. The DNS-amino acids* were identified by paper electrophoresis at $\mathrm{pH} 4.40$ in a flat-plate apparatus (Locarte Co. Ltd., London, S.W. 7). Ambiguities of identification were resolved by cutting out the spots and stitching them to another sheet of paper for electrophoresis at $\mathrm{pH} 2.0$ or chromatography in light petroleum (b.p. 100-120 $0^{\circ}$ )-acetic acid-water (10:9:1, by vol.) (Boulton \& Bush, 1964).

Phenyl isothiocyanate degradation of elastase. DIP. elastase (5 mg.) in $8 \mathrm{ml}$. of $8 \mathrm{M}$-urea was allowed to react at pH 9.0 with $0.2 \mathrm{ml}$. of $10 \%(\mathrm{v} / \mathrm{v})$ phenyl isothiocyanate in redistilled dioxan in a pH-stat at $37^{\circ}$ (Fraenkel-Conrat, Harris \& Levy, 1955). After $2 \frac{1}{2} \mathrm{hr}$. the uptake of $\mathrm{NaOH}$ was complete and the excess of reagent was extracted with benzene and cyclohexane. The phenylthio carbamoyl-protein was precipitated during dialysis against water and this precipitate was spun down, washed with acetone and dried in vacuo. Cyclization with $1 \mathrm{ml}$. of anhydrous trifluoroacetic acid (Konigsberg \& Hill, 1962) was carried out for $3 \mathrm{hr}$. at room temperature. The solvent was removed in vacuo over $\mathrm{NaOH}$ and the dry powder was extracted with acetone. The acetone extract was taken to dryness and treated with $1 \mathrm{ml}$. of $3 \mathrm{~N}-\mathrm{HCl}$ for $3 \mathrm{hr}$. at $37^{\circ}$. After diluting to $1 \mathrm{~N}-\mathrm{HCl}$, the phenylthiohydantoin was extracted with ethyl acetate and evaporated to dryness. The spectrum of the phenylthiohydantoin in ethanol solution showed a distinct peak at $270 \mathrm{~m} \mu$ from which the yield was calculated. The residual protein was dissolved in $8 \mathrm{ml}$. of $8 \mathrm{M}$-urea and recycled.

Peptic peptides from the N-terminus. Elastase (25 mg.) was allowed to react with fluorodinitrobenzene in $8 \mathrm{M}$-urea (Fraenkel-Conrat et al. 1955). The solution was extracted with ether and dialysed against $1 \mathrm{mN}-\mathrm{HCl}$, giving a precipitate of DNP-protein that was spun down and washed with acetone and ether.

This powder was dissolved in $0.2 \mathrm{ml}$. of $98 \%(\mathrm{v} / \mathrm{v})$ formic acid and gave a fine precipitate when diluted to $4 \mathrm{ml}$. to give a final concentration of $5 \%$ formic acid. Pepsin (2.5 mg.) was added and digestion was carried out overnight at $37^{\circ}$. The DNP-peptides were then exhaustively extracted into ethyl acetate and submitted to paper electrophoresis at pH6.5 in a flat-plate apparatus. The yellow DNP-peptides were eluted with $0 \cdot 1 \mathrm{~N}-\mathrm{NH}_{3}$.

After acid hydrolysis of the DNP-peptides, the DNPamino acids were extracted with ether and identified by two-dimensional paper chromatography in 2-methylbutan2-ol-2 $\mathrm{N}-\mathrm{NH}_{3}(4: 1, \mathrm{v} / \mathrm{v})$ followed by $1 \cdot 5$ M-sodium phosphate, pH 6. The aqueous phase was analysed quantitatively in the amino acid analyser.

\section{RESULTS}

\section{Preparation and purification of DIP-elastase}

To avoid the danger of autolytic cleavages during purification and subsequent manipulation, elastase

* Abbreviations: DNS, 1-dimethylaminonaphthalene-5sulphonyl; DIP, di-isopropyl phosphoryl; $\mathrm{CySO}_{3} \mathrm{H}$, cysteic acid; $\mathrm{MetSO}_{2}$, methionine sulphone; Asx, aspartic acid or asparagine; Glx, glutamic acid or glutamine.

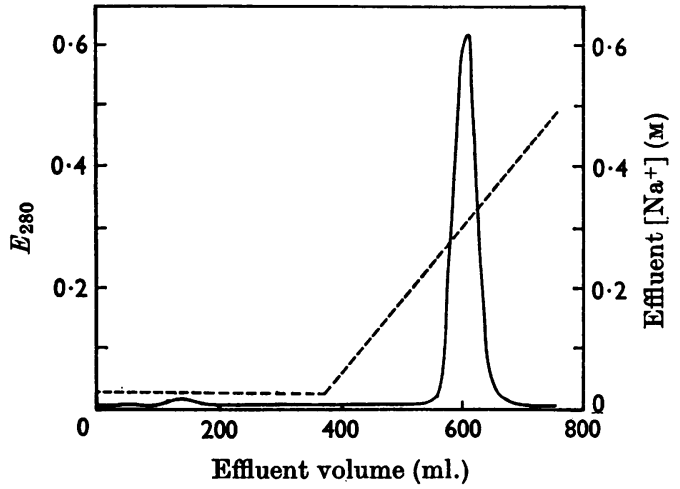

Fig. 1. Elution diagram of DIP-elastase (about $170 \mathrm{mg}$.) on a CM-cellulose column $(2 \mathrm{~cm} . \times 35 \mathrm{~cm}$.) in $0.02 \mathrm{M}$-sodium acetate, $\mathrm{pH} 5 \cdot 0$, with a linear gradient of $\mathrm{NaCl}:-, E_{280}$; ---- , effluent concn. of $\mathrm{Na}^{+}$ion.

was converted into its inactive DIP derivative (Naughton \& Sanger, 1961). Crystalline elastase (750 mg.) suspended in $20 \mathrm{ml}$. of water was adjusted to $\mathrm{pH} 8.5$ and stirred overnight at $2^{\circ}$ with $0.5 \mathrm{ml}$. of ethanol containing $75 \mu \mathrm{l}$. of di-isopropyl phosphorofluoridate. The suspension dissolved when adjusted to $\mathrm{pH} 10$ with sodium hydroxide and this solution was diluted with $200 \mathrm{ml}$. of $0.01 \mathrm{~N}$-sodium borate, $\mathrm{pH} \mathrm{8.7,} \mathrm{and} \mathrm{stirred} \mathrm{for} 4 \mathrm{hr}$. at $2^{\circ}$ with a $200 \mathrm{ml}$. bed volume of DEAE-Sephadex (A50) that had been equilibrated with the borate buffer. The mixture was filtered, and the filtrate $(215 \mathrm{ml}$.) was adjusted to $\mathrm{pH} 5.0$ with acetic acid and pumped into a column of Whatman CM-cellulose $(2 \mathrm{~cm} . \times 35 \mathrm{~cm}$.) that had been equilibrated with $0.02 \mathrm{M}$-sodium acetate, pH 5.0. Fig. 1 shows the elution pattern of this column when developed with a gradient of sodium chloride at $36 \mathrm{ml}$./hr. The single peak, eluted at $0.29 \mathrm{M}$-sodium chloride, had an extinction at $280 \mathrm{~m} \mu$ equivalent to 257 density units, which is $85 \%$ of the filtrate applied. The elution pattern of a similar column with a sample of uninhibited elastase, which had been freshly prepared from Pancreatin as described in the Methods section, showed an almost identical pattern with a major peak, which eluted at about $0.22 \mathrm{M}$-sodium chloride, preceded by two minor components, which represented less than $5 \%$ of the total extinction at $280 \mathrm{~m} \mu$. The elastase activity was coincident with the main peak and the minor components were completely inactive. Hence the purification procedure of Smillie \& Hartley (1966) gives chromatographically pure elastase.

\section{Amino acid composition of DIP-elastase}

Samples of DIP-elastase from the peak tubes of Fig. 1 were hydrolysed with $5 \cdot 7 \mathrm{~N}$-hydro- 


\section{Table 1. Amino acid analysis of DIP-elastase}

The analytical results are the mean of five analyses on $16 \mathrm{hr}$., $40 \mathrm{hr}$. and $72 \mathrm{hr}$. hydrolysates of DIP-elastase plus $16 \mathrm{hr}$. and $72 \mathrm{hr}$. hydrolysates of oxidized DIP-elastase. Threonine and serine values are corrected for destruction by extrapolation to zero hydrolysis time and valine and isoleucine values are corrected for incomplete hydrolysis by extrapolation to infinite hydrolysis time. Aspartic acid and tyrosine values are the means of the three analyses on the unoxidized protein only since the oxidized protein gives high aspartic acid values from hydrolysis of oxidized tryptophan and low tyrosine values because of chlorination of the aromatic ring. Half-cystine values are calculated from cysteic acid in the oxidized protein and methionine values from methionine in the unoxidized and methionine sulphone in the oxidized protein. Tryptophan values are calculated by the spectrophotometric method of Beaven \& Holiday (1952) applied to a peptic digest of elastase. The composition of bovine trypsin is from the sequence of Walsh \& Neurath (1964), and that of bovine $\alpha$-chymotrypsin A from the sequence of Hartley \& Kauffman (1966).

\begin{tabular}{|c|c|c|c|c|c|}
\hline Amino acid & $\begin{array}{c}\text { Analysis } \\
(\mathrm{m} \mu \text { moles })\end{array}$ & Mean ratio & $\begin{array}{c}\text { Probable } \\
\text { composition }\end{array}$ & Trypsin & $\begin{array}{l}\alpha \text {-Chymo- } \\
\text { trypsin A }\end{array}$ \\
\hline Lys & $16 \pm 2$ & $2 \cdot 9 \pm 0 \cdot 3$ & 3 & 14 & 14 \\
\hline His & $28 \pm 2$ & $4.9 \pm 0.3$ & 5 & 3 & 2 \\
\hline Arg & $60 \pm 4$ & $10.4 \pm 0.6$ & 11 & 2 & 3 \\
\hline Asp & $130 \pm 2$ & $22 \cdot 9 \pm 0.4$ & 23 & 22 & 22 \\
\hline Thr & $105^{--}$ & $18 \cdot 0$ & 18 & 10 & 22 \\
\hline Ser & 127 & $22 \cdot 0$ & 22 & 33 & 27 \\
\hline Glu & $109 \pm 3$ & $18 \cdot 8 \pm 0.5$ & 19 & 14 & 15 \\
\hline Pro & $40 \pm 4$ & $6 \cdot 8 \pm 0.6$ & 7 & 9 & 9 \\
\hline Gly & $149 \pm 6$ & $25 \cdot 8 \pm 1 \cdot 1$ & 26 & 25 & 23 \\
\hline Ala & $98 \pm 2$ & $17 \cdot 0 \pm 0 \cdot 3$ & 17 & 14 & 22 \\
\hline CyS & $44 \pm 1$ & $7 \cdot 6 \pm 0 \cdot 2$ & 8 & 12 & 10 \\
\hline Val & $150^{--}$ & $26 \cdot 0^{-}$ & 26 & 17 & 23 \\
\hline Met & $10 \pm 1$ & $1 \cdot 7 \pm 0.2$ & 2 & 2 & 2 \\
\hline Ile & $55^{-2}$ & $9 \cdot 6$ & 10 & 15 & 10 \\
\hline Leu & $99 \pm 3$ & $17 \cdot 2 \pm 0 \cdot 4$ & 17 & 14 & 19 \\
\hline Tyr & $59 \pm 3$ & $10 \cdot 1 \pm 0.5$ & 10 & 10 & 4 \\
\hline Phe & $19 \pm 1$ & $3.3 \pm 0.2$ & 3 & 3 & 6 \\
\hline Trp & & $7 \cdot 0 \pm 0.5$ & 7 & 4 & 8 \\
\hline Total & & & 234 & 223 & 241 \\
\hline
\end{tabular}

chloric acid for 16, 40 and $72 \mathrm{hr}$. Similar samples from these peak tubes were dialysed against 0.1 mm-sodium hydrogen carbonate, freeze-dried, oxidized with performic acid (Hirs, 1956) and hydrolysed for $16 \mathrm{hr}$. or $72 \mathrm{hr}$. to determine cystine as cysteic acid. Tryptophan was determined by the spectrophotometric method of Beaven \& Holiday (1952) applied to a peptic digest of elastase to eliminate effects of tertiary structure on the spectrum of tyrosine and tryptophan.

The results (Table 1) show that porcine elastase differs appreciably in composition from other pancreatic proteinases, notably in the low lysine and high arginine content and in the half-cystine content which indicates four disulphide bridges compared with five in bovine chymotrypsinogen $A$ and chymotrypsinogen $B$ and six in bovine trypsinogen.

\section{$\mathrm{N}$-Terminus}

Phenyl isothiocyanate degradation was performed on $5 \mathrm{mg}$. of DIP-elastase. The spectrum of the first phenylthiohydantoin showed a peak at
$270 \mathrm{~m} \mu$ corresponding to a yield of $0.175 \mu \mathrm{mole}$ of phenylthiohydantoin. Chromatography of onethird of this on starch-paper in heptane-pyridine (Sjöquist, 1960) gave a single spot corresponding to marker valine phenylthiohydantoin when dipped in iodine-azide reagent. The remaining two-thirds gave $0.032 \mu \mathrm{mole}$ of valine and $0.011 \mu \mathrm{mole}$ of glycine after $16 \mathrm{hr}$. hydrolysis in $5 \cdot 7 \mathrm{~N}$-hydrochloric acid at $150^{\circ}$.

The second round of Edman degradation gave $0 \cdot 180 \mu$ mole of phenylthiohydantoin, which again proved to be entirely that of valine by chromatography. Acid hydrolysis of two-thirds of this phenylthiohydantoin regenerated $0.028 \mu \mathrm{mole}$ of valine and $0.008 \mu$ mole of glycine. (The glycine is probably a breakdown product of the phenylthiohydantoin.)

No phenylthiohydantoin was obtained at the third stage of the degradation, even after the entire residual phenylthiocarbamoyl-protein had been treated with $3 \mathrm{~N}$-hydrochloric acid for $5 \mathrm{hr}$. at $37^{\circ}$. The results indicate that DIP-elastase has a single $N$-terminal sequence: Val-Val- recovered in $90 \%$ 
yield based on a molecular weight of 25000 (Lewis et al. 1956).

\section{Peptic peptide from the $\mathrm{N}$-terminus}

The ethyl acetate extract from a peptic digest of the DNP-protein was separated by electrophoresis at $\mathrm{pH} 6.5$ into dinitrophenol plus a DNP-peptide with a mobility 0.8 that of dinitrophenol. Acid hydrolysis showed that this peptide had the composition: DNP-Val, Thr (0.7), Glu (1.1), Gly $(2 \cdot 0)$, Val $(1 \cdot 0)$. The sequence of this peptide was determined as follows. A papain digest of the peptide was acidified and extracted with ethyl acetate to isolate the DNP-fragment from the $N$-terminus. Electrophoresis of this extract at $\mathrm{pH} 6.5$ gave a single yellow peptide (P1) whose composition was: DNP-Val, Val (0.8), Gly (1.0). A carboxypeptidase digest of this peptide liberated glycine together with a trace of valine. The aqueous phase of the papain digest was subjected to electrophoresis at $\mathrm{pH} 6.5$ and gave a single acidic peptide (P2) with mobility -0.88 (peptide mobilities are relative to 1 -dimethylaminonaphthalene-5-sulphonic acid -1.0) that stained yellow with cadmium-ninhydrin reagent. Its composition was: $\operatorname{Thr}(1 \cdot 0)$, Glu (1.0), Gly (1.0); its mobility at $\mathrm{pH} 6.5$ indicates that peptide $\mathrm{P2}$ contains glutamic acid rather than glutamine. The 'dansyl'-Edman procedure gave DNS-Gly and then DNS-Thr at successive steps, and left free glutamic acid after the second cyclization step, so the sequence of the second papain fragment is: Gly-Thr-Glu.

Hence the sequence of the peptic peptide from the $N$-terminus of elastase is :

$$
\begin{aligned}
& \text { Papain } \\
& \text { DNP-Val-Val-Gly-Gly-Thr-Glu } \\
& \longmapsto \underset{\mathrm{P} 1}{\leftarrow}-\frac{\mathrm{P} 2}{\longrightarrow}
\end{aligned}
$$

\section{Cystine peptides in a peptic digest of elastase}

The characteristic $\mathrm{pH} 6.5 / \mathrm{pH} 6.5$ diagonal 'map' of cysteic acid peptides in a peptic digest of elastase is shown in Fig. 2. In the procedure of Brown \& Hartley (1966) peptides that were originally joined by a disulphide bridge lie vertically beneath each other in such a pattern. There are four such groups of cysteic acid peptides, corresponding to cystine peptides in bands A-D in the first dimension of electrophoresis.

Band $A$. Although there are four cysteic acid peptides in this band, they all arise from a single cystine sequence by different peptic cleavages. We isolated these peptides by cutting out band $A$ from the original $\mathrm{pH6} .5$ electrophoresis, oxidizing the strip with performic acid vapour and repeating

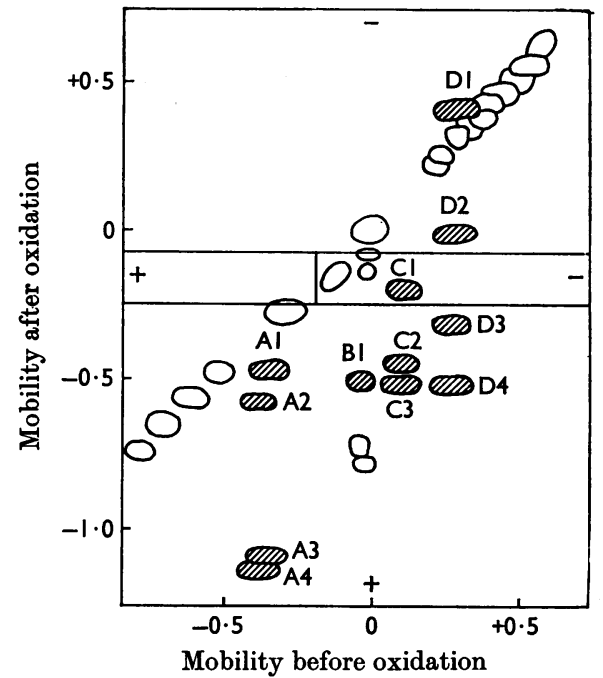

Fig. 2. 'Cystine diagonal map' of a peptic digest of elastase. Electrophoresis was at $\mathrm{pH6.5}$ in both dimensions. The origin was the vertical line on the sewn strip. The major cysteic acid peptides are shaded. Mobilities are relative to 1-dimethylaminonaphthalene-5-sulphonic acid $=-1 \cdot 0$.

electrophoresis at $\mathrm{pH} 6 \cdot 5$. Bands of the cysteic acid peptides A1-A4 were thus obtained. Peptide A1 was still impure at this stage, being contaminated with peptides lacking cysteic acid from the 'diagonal' together with a trace of cysteic acid peptide resembling peptide D4 (see below), but it was purified by further electrophoresis at $\mathrm{pH} 2 \cdot 0$ and $\mathrm{pH} 8.9$.

Table 2 shows the compositions of these peptides, which clearly arise from a single disulphide bridge.

$B$ and $B$. Only faint ninhydrin spots lie off the diagonal in this band. These are probably minor peptic cleavages around disulphide bridges that will be represented elsewhere in the diagonal 'map' by other major products. They might, however, represent a difforent disulphide bridge. To rule out this possibility, we isolated the strongest of these peptides, B1, and determined its composition and $N$-terminus. The results suggested that peptide $\mathrm{Bl}$ was identical with peptide Al, and is presumably linked to a less acidic peptide derived from the peptide A3 or A4 sequence. Hence it is probable that all the cysteic acid peptides in this band are minor varieties of sequences represented elsewhere in the diagonal 'map'.

$B$ and $C$. The main peptides in this band are derived from the 'histidine-loop' disulphide bridge (Smillie \& Hartley, 1965). Peptides C1, C2 and C3 all give a positive test for histidine with Pauly reagent (Dent, 1947) but only peptide C2 shows any appreciable reaction with ninhydrin reagent. Peptides Cl and C3 both have a strong blue 


\section{Table 2. Cysteic acid peptides from a peptic digest of elastase}

Compositions are expressed as uncorrected ratios of amino acids after $20 \mathrm{hr}$. hydrolysis (but $16 \mathrm{hr}$. for peptide A3 and $40 \mathrm{hr}$. for peptides D1 and D2). Peptide A4 was analysed only qualitatively after electrophoresis of a hydrolysate at $\mathrm{pH} 2$. Mobilities of peptides at $\mathrm{pH} 6.5$ are expressed relative to 1-dimethylaminonaphthalene-5sulphonic acid $=-\mathbf{1} \cdot 0$.

\begin{tabular}{|c|c|c|c|}
\hline Peptide & $\begin{array}{l}\text { Mobility } \\
\text { at pH6.5 }\end{array}$ & Composition & Comment \\
\hline Al & -0.48 & $\mathrm{CySO}_{3} \mathrm{H}(0 \cdot 9), \operatorname{Ser}(4 \cdot 5), \operatorname{Ala}(1 \cdot 2), \operatorname{Ile}(1 \cdot 0), \operatorname{Tyr}(0 \cdot 9), \operatorname{Asp}(0 \cdot 3)$ & $\begin{array}{l}N \text {-Terminal Ala, } C \text {-terminal } \\
\text { Tyr }\end{array}$ \\
\hline A2 & -0.60 & $\mathrm{CySO}_{3} \mathrm{H}(+), \operatorname{Ser}(+++), \mathrm{Ala}(+), \mathrm{Ile}(+)$ & Qualitative analysis \\
\hline A3 & $-1 \cdot 10$ & $\mathrm{CySO}_{3} \mathrm{H}(0 \cdot 5), \operatorname{Asp}(1 \cdot 0), \operatorname{Gly}(1 \cdot 8)$, Ala, (1.0) Val (0.5), $\mathrm{MetSO}_{2}(0 \cdot 3)$ & $16 \mathrm{hr}$. hydrolysis \\
\hline A4 & $-1 \cdot 16$ & $\mathrm{CySO}_{3} \mathrm{H}(0 \cdot 8), \operatorname{Asp}(1 \cdot 0), \operatorname{Gly}(2 \cdot 0), \operatorname{Ala}(1 \cdot 1), \operatorname{Val}(0 \cdot 8)$ & $N$-Terminal Val \\
\hline $\mathrm{Cl}$ & -0.21 & $\begin{array}{l}\mathrm{CySO}_{3} \mathrm{H}(1 \cdot 0) \text {, Asp }(0 \cdot 4) \text {, Thr }(1 \cdot 9) \text {, Ser }(0 \cdot 8) \text {, Glu }(0 \cdot 3) \text {, Gly }(2 \cdot 5) \text {, } \\
\text { Ala }(1 \cdot 1) \text {, Val }(0 \cdot 2) \text {, Leu }(1 \cdot 4) \text {, His }(1 \cdot 0)\end{array}$ & Fluorescent, impure \\
\hline $\mathrm{C} 2$ & $-0 \cdot 48$ & $\begin{array}{l}\mathrm{CySO}_{3} \mathrm{H}(1 \cdot 1) \text {, Asp }(1 \cdot 3) \text {, Thr }(0 \cdot 6) \text {, Ser }(1 \cdot 0) \text {, Glu }(1 \cdot 0) \text {, Gly }(0 \cdot 8) \text {, } \\
\text { Ala }(2 \cdot 1) \text {, Val }(0 \cdot 9) \text {, Ile }(0 \cdot 3) \text {, Leu }(0 \cdot 4) \text {, Tyr }(0 \cdot 4), \operatorname{His}(0 \cdot 8), \operatorname{Arg}(0 \cdot 9)\end{array}$ & Impure \\
\hline D1 & +0.65 & $\begin{array}{l}\mathrm{CySO}_{3} \mathrm{H}(0 \cdot 9), \operatorname{Asp}(0 \cdot 8) \text {, Thr }(1 \cdot 7) \text {, Ser }(1 \cdot 1) \text {, Pro }(+) \text {, Gly }(1 \cdot 2) \text {, } \\
\text { Val (2.8), Leu (1.1), Phe }(0 \cdot 8) \text {, Lys }(0 \cdot 9) \text {, Arg }(1 \cdot 7)\end{array}$ & $\begin{array}{l}40 \mathrm{hr} \text {. hydrolysis, Pro quali- } \\
\text { tative, } N \text {-terminal Val }\end{array}$ \\
\hline D2 & $0 \cdot 00$ & $\begin{array}{l}\mathrm{CySO}_{3} \mathrm{H}(0 \cdot 7), \operatorname{Asp}(1 \cdot 0) \text {, Ser }(0 \cdot 7) \text {, Gly }(1 \cdot 1) \text {, Val }(0 \cdot 9) \text {, Leu }(1 \cdot 0) \text {, } \\
\operatorname{Arg}(1 \cdot 0)\end{array}$ & $\begin{array}{l}40 \mathrm{hr} \text {. hydrolysis, } N \\
\text { terminal Val }\end{array}$ \\
\hline D3 & $-0 \cdot 31$ & $\begin{array}{l}\mathrm{CySO}_{3} \mathrm{H}(1 \cdot 6), \operatorname{Asp}(2 \cdot 0) \text {, Ser }(2 \cdot 1) \text {, Glu }(1 \cdot 9) \text {, Pro }(+) \text {, Gly }(5 \cdot 0) \text {, } \\
\text { Val }(1 \cdot 4), \operatorname{Leu}(2 \cdot 0), \operatorname{Tyr}(0 \cdot 6), \operatorname{His}(1 \cdot 0), \operatorname{Arg}(0 \cdot 8)\end{array}$ & $\begin{array}{l}\text { Pro qualitative, } N \text {-ter- } \\
\text { minal Gly }\end{array}$ \\
\hline D4 & -0.48 & $\mathrm{CySO}_{3} \mathrm{H}(1 \cdot 0)$, Asp (1.9), Ser (1.0), Pro (0.7), Ala (0.9), Tyr $(0 \cdot 9)$ & $N$-Terminal Ala \\
\hline
\end{tabular}

fluorescence on paper suggestive of oxidized tryptophan. These three peptides were isolated by pH 6.5 electrophoresis of a $30 \mathrm{~cm}$. band of oxidized band $\mathbf{C}$ and their composition was determined. Although they were rather contaminated, it was clear that peptide C2 corresponded to the peptic peptide El, namely, Ala-Ala-His-CySO $3 \mathrm{H}-\mathrm{Val}$ Asx-Arg-Glx, described by Smillie \& Hartley (1966), whereas peptides C1 and C3 were similar in composition and are probably the same as peptides E3 and E4, namely (Trp)-Ala-His-Thr-CySO 3 H-Gly-GlyThr-Leu, which Smillie \& Hartley (1966) suggested might have oxidized tryptophan products at their $N$-termini. The mobility of these peptides at $\mathrm{pH} 6 \cdot 5$ and at pH 2 suggests that peptide $\mathrm{C2}$ (E1) may have both aspartic acid and glutamic acid, rather than the amides, and that the difference in mobility between peptides C1 (E3) and C3 (E4) may be due to the absence of an $N$-terminal amino group from the latter.

To confirm the postulated $N$-terminal tryptophan in the original cystine parent, we isolated the cystine peptide $\mathrm{C}$ by electrophoresis of band $\mathrm{C}$ at $\mathrm{pH} 3.5$ without any oxidation. As expected, the histidinecontaining peptide was more cationic at this $\mathrm{pH}$ than any underlying contaminants because of the increased positive charge on the two histidine residues. Ehrlich's reagent (Smith, 1953) confirmed that the peptide contained tryptophan, and it was eluted for sequence study.

Band $D$. Four cysteic acid peptides lie in this band, leaving the possibility that two disulphide bridges are involved. In this case, the way in which these peptides are linked would be ambiguous, so we eluted half of the band $D$ (corresponding to the yield from $100 \mathrm{mg}$. elastase) from the original pH 6.5 ionophoresis for separate treatment.

The remainder of band $D$ was oxidized and re-run at $\mathrm{pH} 6 \cdot 5$, yielding peptides D1-D4. Peptide D1 was further purified by electrophoresis at $\mathrm{pH} 8.9$ and peptides D2 and D4 at $\mathrm{pH} 2 \cdot 0$. The amino acid compositions of these peptides (Table 2) suggest that they arise from a three-chain peptide linked by two disulphide bridges. Hence it is necessary to digest this peptide further to determine the way in which the cysteic acid peptides are linked.

\section{Chymotryptic digestion of peptides from band $D$}

To resolve the ambiguity between the two disulphide bridges of band $D$, the eluate from this band was digested overnight at room temperature with chymotrypsin (2mg.) in $2 \mathrm{ml}$. of $0.5 \%$ ammonium hydrogen carbonate, $\mathrm{pH}$. This digest was then applied to paper as a $40 \mathrm{~cm}$. band and separated by electrophoresis at $\mathrm{pH} 6 \cdot 5$. A $2 \mathrm{~cm}$. marker strip from this sheet was treated with performic acid vapour and gave the $\mathrm{pH} 6.5 / \mathrm{pH} 6.5$ diagonal 'map' shown in Fig. 3. Three major groups of cysteic acid peptides are observed: bands DcA and DcC clearly contain only one cystine peptide, but the neutral band DcB is more complex. By following the procedure of Brown \& Hartley (1966), we showed that peptide DcBl is linked to peptide DcB4 by separating a $3 \mathrm{~cm}$. strip of band DcB by electrophoresis at $\mathrm{pH} 2$. A pH 2/pH 6.5 diagonal 'map' was 
then obtained in the usual way, which clearly showed that peptides DcBl and DcB4 arose from the same cystine precursor, whereas peptides DcB2 and DcB3 were mixtures of several cysteic acid peptides present in lower yield.

The peptides DcAl and DcA2 were isolated on a preparative scale by oxidation of band DcA and electrophoresis at $\mathrm{pH} 6.5$, and peptides $\mathrm{DcBl}$ and DcB4 were similarly prepared from band DcB. Band DcC was further purified by electrophoresis at $\mathrm{pH} 3.5$ before oxidation, to separate it more positively from neutral peptides. After oxidation, it gave peptides $\mathrm{DcCl}$ and $\mathrm{DcC} 2$, as expected.

Table 3 shows the composition of all these chymotryptic fragments of the peptic peptide present in band $D$ (Fig. 2). It is clear that they establish unequivocally the way in which the four half-cystine residues are linked.

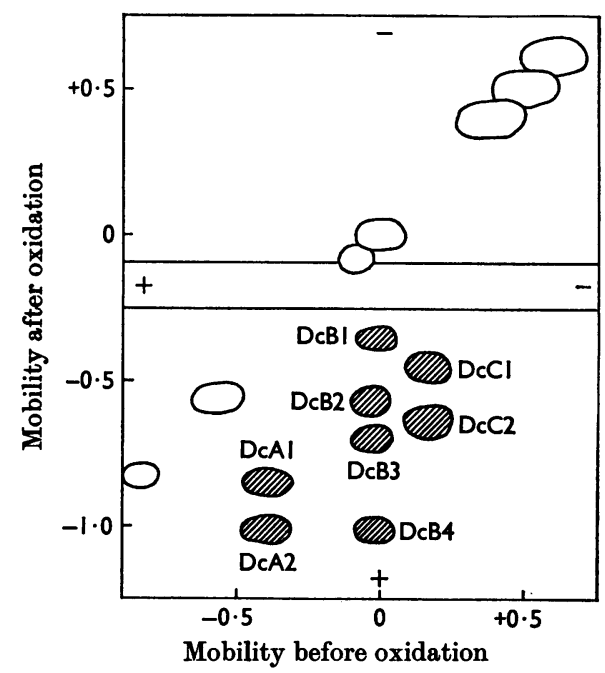

Fig. 3. 'Cystine diagonal map' of a chymotryptic digest of peptides eluted from band $D$ of Fig. 2. Details are as given in Fig. 2.

\section{Sequence studies of the cysteic acid peptides}

Peptide A1. This peptide still contains traces of contaminating peptide D4, which was very difficult to remove since it has a very similar size and charge pattern, but the amino acid analysis (Table 2)

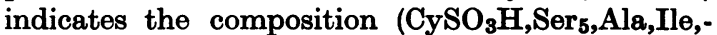
Tyr). 'Dansyl'-Edman analysis gave DNS-alanine as the $N$-terminal residue, DNS-isoleucine after one round of Edman degradation, DNS-cysteic acid next and then DNS-serine. Digestion of peptide Al with carboxypeptidase A liberated tyrosine together with a trace of serine. These results, summarized in Table 4, suggest the sequence Ala-Ile-CySO ${ }_{3} \mathrm{H}$-SerSer-Ser-Ser-Ser-Tyr for peptide Al.

Peptide A2. Qualitative analysis of peptide A2 (Table 2) shows that its composition is very similar to that of peptide Al except that tyrosine is absent, and, since the bond $N$-terminal to tyrosine is a wellestablished point of peptic cleavage, the sequence of peptide A2 is probably Ala-Ile-CySO ${ }_{3} \mathrm{H}$-Ser-SerSer-Ser-Ser.

Peptide A3. The subtractive Edman technique of Konigsberg \& Hill (1962) suggested that the $\mathrm{N}$-terminal sequence of this peptide was $\mathrm{MetSO}_{2}$ Val-CySO ${ }_{3} \mathrm{H}-$, and this was confirmed by the 'dansyl'-Edman method, which gave DNS-methionine sulphone, DNS-valine, DNS-cysteic acid and DNS-alanine respectively at successive steps, with very low yields of DNS-amino acid thereafter. No amino acids were liberated by digestion with carboxypeptidase A. A subtilisin digest of peptide A3 was separated by electrophoresis at $\mathrm{pH} 2$, giving peptide A3sl (neutral at $\mathrm{pH} 2$ ) and peptide A3s2 (mobility 0.73 relative to glycine at $\mathrm{pH} 2$ ). Peptide A3s1 had the composition $\left(\mathrm{CySO}_{3} \mathrm{H}, \mathrm{MetSO}_{2}\right.$, Gly,Ala, Val) by qualitative paper analysis and gave DNS-methionine sulphone by the 'dansyl' technique. Quantitative analysis of peptide A3s2 gave the composition Asp (1.0), Gly (1.0); the 'dansyl' technique gave glycine as the $N$-terminus. Hence the sequence of peptide A3, summarized in Table 4, is $\mathrm{MetSO}_{2}$-Val-CySO ${ }_{3} \mathrm{H}$-Ala-Gly-Gly-Asp.

Table 3. Cysteic acid peptides from a chymotryptic digest of the cystine peptides in band D (Fig. 2)

\begin{tabular}{|c|c|c|c|}
\hline Peptide & $\begin{array}{l}\text { Mobility } \\
\text { at pH6.5 }\end{array}$ & Details are as given in Table 2. & Comment \\
\hline DeAl & -0.91 & $\begin{array}{l}\mathrm{CySO}_{3} \mathrm{H}(1 \cdot 0) \text {, Asp }(1 \cdot 2) \text {, Ser }(2 \cdot 0) \text {, Glu }(0 \cdot 9) \text {, Pro }(+) \text {, Gly }(4 \cdot 1) \text {, } \\
\text { Leu }(1 \cdot 0)\end{array}$ & $\begin{array}{l}\text { Pro qualitative, } \\
N \text {-terminal Ser }\end{array}$ \\
\hline DoA2 & -1.03 & $\mathrm{CySO}_{3} \mathrm{H}(0 \cdot 8), \operatorname{Asp}(1 \cdot 1)$, Gly $(1 \cdot 3)$ & \\
\hline DcB1 & $-0 \cdot 40$ & $\begin{array}{l}\mathrm{CySO}_{3} \mathrm{H}(1 \cdot 0), \operatorname{Asp}(0 \cdot 9), \operatorname{Ser}(2 \cdot 1) \text {, Glu }(1 \cdot 0) \text {, Pro }(+) \text {, Gly (4.2), } \\
\operatorname{Val}(1 \cdot 1), \operatorname{Leu}(1 \cdot 1), \operatorname{Arg}(+)\end{array}$ & $\begin{array}{l}\text { Pro qualitative, } \\
N \text {-terminal Gly }\end{array}$ \\
\hline DcB4 & -1.03 & $\mathrm{CySO}_{3} \mathrm{H}(0 \cdot 7), \operatorname{Asp}(1 \cdot 0)$, Gly $(1 \cdot 0)$ & $N$-Terminal Gly \\
\hline $\mathrm{DeCl}$ & -0.48 & $\mathrm{CySO}_{3} \mathrm{H}(1 \cdot 0), \operatorname{Asp}(2 \cdot 3), \operatorname{Ser}(1 \cdot 0), \operatorname{Pro}(+), \operatorname{Ala}(0 \cdot 8), \operatorname{Tyr}(1 \cdot 1)$ & Pro qualitative \\
\hline DeC2 & -0.74 & $\mathrm{CySO}_{3} \mathrm{H}(1 \cdot 1)$, Leu $(1 \cdot 0), \mathrm{His}(0 \cdot 7)$ & \\
\hline
\end{tabular}


Table 4. Summary of the sequence studies of the peptic cysteic acid peptides

Peptide

Al:

A2:

A3:

A4:

$\mathrm{Cl} \& \mathrm{C3}$ :

C2:

D1:

D2:

D4:

Sequence

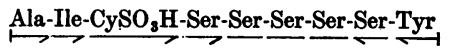

Ala-Ile-CySO ${ }_{3} \mathrm{H}$-Ser-Ser-Ser-Ser-Ser

$\stackrel{\mathrm{MetSO}_{2}}{\longrightarrow}$-Val-CySO

$\longmapsto \stackrel{\text { A3s1 }}{\longrightarrow} \longrightarrow \stackrel{\text { A3s2 }}{\longrightarrow}$

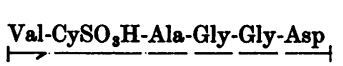

(OxTrp)-Ala-His-Thr-CySO 8 H-Gly-Gly-Thr-Leu

Thr-Ala-Ala-His-CySO ${ }_{3} \mathrm{H}$-Val-Asp-Arg-Glu

Smillie \& Hartley (1966)

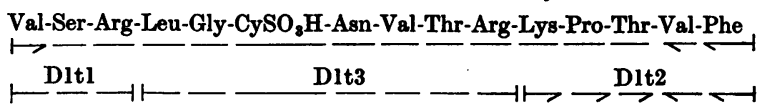

Val-Ser-Arg-Leu-Gly-CySO ${ }_{3} \mathrm{H}-\mathrm{Asn}-\mathrm{Val}$

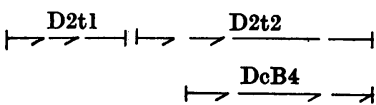

D3 : Gly-Val-Arg-Ser-Gly-CySO,H-Gln-Gly-Asp-Ser-Gly-(Gly,Pro)-Leu-His-CySO ${ }_{3} H-L e u-V a l-A s n-G l n-T y r$

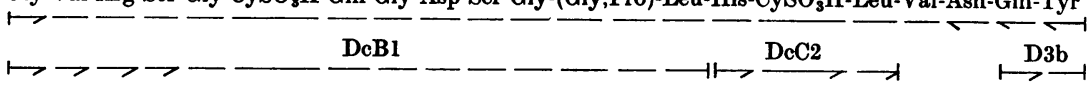

$\longrightarrow \longrightarrow \longrightarrow \stackrel{\text { DcAl }}{\longrightarrow}$

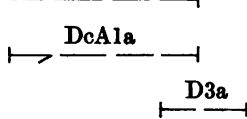

Ala-Asn-Asn-Ser-Pro-CySO $3 \mathrm{H}-\mathrm{I}$-yr

$\mathrm{DcCl}$

Peptide A4. The composition of this peptide (Table 2) is the same as that of peptide A3 less one methionine residue. Since it gave $N$-terminal valine by the 'dansyl' method, the sequence of peptide A3 is almost certainly Val-CySO $3 \mathrm{H}-\mathrm{Ala}-\mathrm{Gly}-\mathrm{Gly}-\mathrm{Asp}$.

Peptide $C$. Performic acid oxidation of a portion of this peptide gave products whose mobility at pH 6.5, fluorescence and qualitative amino acid analysis were identical with those of peptides C1, C2 and C3 (Fig. 2) discussed above. Peptide C2 gave $N$-terminal alanine together with threonine by the 'dansyl' technique and its mobility suggests that free aspartic acid and glutamic acid are present. No $N$-terminal residue could be detected in peptide $\mathrm{Cl}$ or C3, but all three products must arise from the same precursor cystine peptide.

To prove that tryptophan was $N$-terminal we treated about $0.1 \mu$ mole of peptide $\mathrm{C}$ for $2 \mathrm{hr}$. at $37^{\circ}$ with $0.25 \mathrm{mg}$. of DNS chloride in $0.4 \mathrm{ml}$. of $0.2 \mathrm{M}$ sodium hydrogen carbonate containing $25 \%(\mathrm{v} / \mathrm{v})$ of acetone. After evaporation of the mixture to dryness, it was digested with $0.2 \mathrm{mg}$. of chymotrypsin in $0 \cdot 2 \mathrm{ml}$. of water for $6 \mathrm{hr}$. at $37^{\circ}$. The digest was adjusted to $\mathrm{pH} 3$ with hydrochloric acid and extracted with $n$-butyl acetate until no more fluorescence could be detected in the organic phase. Back-extraction with 0.1 N-ammonia gave a yellowfluorescent aqueous solution that was submitted to paper electrophoresis at $\mathrm{pH}_{4.4}$ on a flat-plate apparatus. Two fluorescent bands were seen, one of which was identical in mobility with an authentic sample of DNS-tryptophan, whereas the second ran close to DNS-glycine and is probably residual DNS-peptide. The release of DNS-tryptophan by chymotryptic digestion of the DNS-peptide shows that tryptophan must have been one of the two $N$-terminal amino acids in the cystine peptide; the other is, of course, alanine or threonine in the C2 fragment, which is a mixture of the peptides El and E2 described by Smillie \& Hartley (1966).

Peptide D1. Amino acid analysis of this peptide (Table 2) suggests the composition $\left(\mathrm{CySO}_{3} \mathrm{H}, \mathrm{Asx}\right.$,$\mathrm{Thr}_{2}$,Ser,Pro,Gly, Val, ,Leu,Phe,Lys,Arg I $_{\text {( }}$ and the mobility at pH6.5 tentatively suggests that the aspartic acid derives from an asparagine residue. Valine was found to be $N$-terminal by the 'dansyl' 


\section{Table 5. Peptides from tryptic digests of peptides D1 and D2}

\begin{tabular}{|c|c|c|c|}
\hline \multicolumn{4}{|c|}{ Details are as given in Table 2.} \\
\hline Peptide & $\begin{array}{l}\text { Mobility } \\
\text { at pH6.5 }\end{array}$ & Composition & Comment \\
\hline D1t1 & +0.72 & $\operatorname{Ser}(+), \operatorname{Val}(+), \operatorname{Arg}(+)$ & Qualitative analysis \\
\hline Dlt2 & +0.48 & Thr $(1 \cdot 0)$, Pro $(1 \cdot 2)$, Val $(1 \cdot 0)$, Phe $(1 \cdot 1)$, Lys $(+)$ & Lys qualitative \\
\hline Dlt3 & $0 \cdot 00$ & $\begin{array}{l}\mathrm{CySO}_{3} \mathrm{H}(0 \cdot 9), \operatorname{Asp}(0 \cdot 9) \text {, Thr }(0 \cdot 9) \text {, Gly }(1 \cdot 2) \text {, Val }(1 \cdot 1) \text {, Leu }(0 \cdot 9) \text {, } \\
\text { Arg }(1 \cdot 1)\end{array}$ & $\begin{array}{l}\text { Mobility } 0.36 \text { at } \mathrm{pH} 2 \text { rela- } \\
\text { tive to DNS-Arg }\end{array}$ \\
\hline D2t1 & $+0 \cdot 73$ & $\operatorname{Ser}(1 \cdot 0), \operatorname{Val}(1 \cdot 0), \operatorname{Arg}(0 \cdot 8)$ & \\
\hline D2t2 & -0.81 & $\mathrm{CySO}_{3} \mathrm{H}(1 \cdot 0), \operatorname{Asp}(1 \cdot 0)$, Gly $(1 \cdot 0)$, Leu $(1 \cdot 0)$ & \\
\hline
\end{tabular}

method, and carboxypeptidase liberated only valine and phenylalanine in approximately equal amounts. In some preparations, a minor component of peptide D1 separated on $\mathrm{pH} 6.5$ electrophoresis (mobility 0.69 compared with 0.65 for peptide D1) that had identical composition except that phenylalanine was absent. Hence the $C$-terminal sequence of peptide Dl is probably -Val-Phe.

A tryptic digest of peptide Dl was purified by electrophoresis at $\mathrm{pH} 6.5$ giving two basic peptides D1t1 and D1t2 plus a neutral peptide Dlt3 that was further purified by electrophoresis at pH2. The composition of these peptides is shown in Table 5 . The sequence of peptide D1t2 was established by the 'dansyl'-Edman procedure and by a limited carboxypeptidase digestion (10 min.) that liberated phenylalanine and valine in the ratio $1 \cdot 00: 0.56$ respectively. Hence peptide Dlt2 is Lys-Pro-ThrVal-Phe.

These results, together with the studies below on peptide D2, are summarized in Table 4 and allow us to write the sequence of peptide D1 as Val-Ser-ArgLeu-Gly-CySO 3 H-Asn-Val-Thr-Arg-Lys-Pro-Thr Val-Phe.

Peptide D2. The composition of this peptide, (CySO ${ }_{3} \mathrm{H}, \mathrm{Asp}, \mathrm{Ser}, \mathrm{Gly}, \mathrm{Val}, \mathrm{Leu}, \mathrm{Arg}$ ) (Table 2), suggests that it might be a fragment of peptide D1. Since the peptide is neutral at $\mathrm{pH} 6 \cdot 5$, the aspartic acid must have been in the amide form. A carboxypeptidase digestion yielded about $0.2 \mathrm{~mole}$ of valine/mole of peptide, which suggested to us that we had two species of this peptide, the minor component having $C$-terminal valine. A repeat of this carboxypeptidase digestion yielded valine and asparagine. 'Dansyl'-Edman analysis gave Val-Seras the $N$-terminal sequence.

A tryptic digest of peptide D2 was separated by pH 6.5 electrophoresis into a basic peptide D2tl and an acidic peptide D2t2. The composition (Table 5) and $N$-terminal sequences of these peptides (Table 4) determined by the 'dansyl'-Edman technique allow us to write the sequence of peptide D2 as

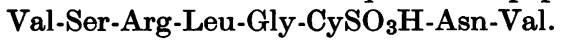

Peptide D3. The composition of this peptide (Table 2) appears to be $\left(\mathrm{CySO}_{3} \mathrm{H}_{2}, \mathrm{Asp}_{2}, \mathrm{Ser}_{2}\right.$, Glu 2 ,Pro,Gly, Val $_{2}, \mathrm{Leu}_{2}, \mathrm{Tyr}, \mathrm{His}, \mathrm{Arg}$ ). Carboxypeptid- ase digestion liberated glutamine and tyrosine in equal amounts, with a trace of asparagine, and the 'dansyl' method showed that glycine was $N$-terminal.

Two peptides were isolated from many present in a partial acid hydrolysate of peptide D3. Peptide D3a was a basic peptide of composition (Leu,His) and peptide D3b was a neutral peptide (Gln,Tyr) giving DNS-Glu by the 'dansyl' method. These results, summarized in Table 4, together with the sequence of some chymotryptic peptides given below, allow us to write the sequence of peptide D3 as Gly-ValArg-Ser-Gly-CySO 3 H-Gln-Gly-Asp-Ser-Gly-(Gly,Pro)-Leu-His-CySO ${ }_{3} \mathrm{H}-\mathrm{Leu}-\mathrm{Val}-\mathrm{Asn}-\mathrm{Gln}-\mathrm{Tyr}$.

Peptide D4. The composition of this peptide (Table 2) and its electrophoretic mobility at pH 6.5 make it clear that it is identical with peptide $\mathrm{DcCl}$ below, which has the sequence Ala-Asn-Asn-SerPro- $\mathrm{CySO}_{3} \mathrm{H}-\mathrm{Tyr}$.

\section{Chymotryptic peptides derived from band $D$}

Band D (Fig. 2) contains a peptic peptide with two disulphide bridges that link peptides D1, D3 and D4. Chymotrypsin splits between bridges of this peptic peptide, and the diagonal 'map' (Fig. 3) shows that the bridges are now found in separate bands. The sequence of these chymotryptic fragments helps to elucidate the sequence of the parent peptic peptide.

Peptide DcAl. The composition of this peptide (Table 3) appears to be $\left(\mathrm{CySO}_{3} \mathrm{H}, \mathrm{Asp}_{\text {,Ser }}, \mathrm{Glu}, \mathrm{Pro}\right.$,$\left.\mathrm{Gly}_{4}, \mathrm{Leu}\right)$. The 'dansyl'-Edman technique gave the $N$-terminal sequence Ser-Gly-CySO $3 \mathrm{H}-\mathrm{Gln}$ Gly-Asp-. A Pronase digest of this peptide gave, as one of the products, a peptide DcAla of composition (Pro,Gly 2,Leu) with $N$-terminal glycine. Hence we may write the sequence Ser-Gly-CySO $\mathrm{CH}_{3} \mathrm{H}-\mathrm{Gln}-\mathrm{Gly}$ Asp-Ser-Gly-(Gly,Pro,Leu). This sequence is almost certainly that surrounding the active-centre serine residue of elastase (Hartley et al. 1959).

Peptide DcA2. The composition, colour with cadmium-ninhydrin reagent and electrophoretic mobility make it certain that this peptide is identical with peptide DcB4, i.e. Gly-CySO $3 \mathrm{H}$-Asn.

Peptide $D c B 1$. The $N$-terminal sequence of this peptide was determined by the 'dansyl'-Edman 
technique to be Gly-Val-Arg-Ser-. Its composition (Table 3) suggests that it is a larger variety of peptide DcA1, namely Gly-Val-Arg-Ser-Gly$\mathrm{CySO}_{3} \mathrm{H}$-Gln-Gly-Asp-Ser-(Gly 2 ,Pro,Leu).

Peptides DcB2 and DcB3. These were mixtures as isolated and were not purified further.

Peptide DcB4. The 'dansyl'-Edman procedure established the $\mathrm{N}$-terminal sequence Gly-CySO${ }_{3} \mathrm{H}$-. The residue after two rounds of cyclization was applied directly to the amino acid analyser and gave a single peak in the position of asparagine.

Peptide $D c C 1$. The sequence of this peptide was determined for six positions by the 'dansyl'-Edman method. The residue, applied without hydrolysis to the amino acid analyser, gave a single peak in the position of tyrosine. It is clearly identical with peptide E7 described by Smillie \& Hartley (1966). Its electrophoretic mobility at $\mathrm{pH} \mathrm{6.5}$ is consistent with the sequence Ala-Asn-Asn-Ser-Pro- $\mathrm{CySO}_{3} \mathrm{H}$ Tyr.

Peptide DcC2. This is identical with peptide E5 described by Smillie \& Hartley (1966) and has the sequence His-CySO ${ }_{3} \mathrm{H}$-Leu.

\section{Disulphide bridges of elastase}

Table 5 summarizes our evidence for the amino acid sequences surrounding the eight half-cystine residues of elastase. The cystine diagonal 'map' of a peptic digest of elastase (Fig. 2) shows that peptides $\mathrm{Al}$ or A2 are linked to peptides A3 or A4, and that peptides $\mathrm{Cl}$ and $\mathrm{C3}$ are linked to peptide C2. Peptide D3 contains two half-cystine residues that are linked to peptide D1 (or peptide D2) and to peptide D4. This remaining ambiguity is resolved by inspection of the diagonal 'map' of a chymotryptic digest of peptide D (Fig. 3), which shows that peptide DcAl, which contains the first halfcystine of peptide D3, is linked to peptide DcA2, which is a fragment of peptide Dl. Moreover, peptide DcC2, the -His-Cys-Leu- fragment of peptide D3, is linked to peptide $\mathrm{DcCl}$, which is identical with the peptic peptide D4. We are therefore able to write the sequences shown in Table 6 for the four disulphide bridges of elastase.

\section{DISCUSSION}

The homologies of amino acid sequence between porcine elastase and bovine chymotrypsinogen A, chymotrypsinogen $B$ and trypsin are illustrated in Table 7. Of the 83 residues of the elastase sequence shown here, 43 are identical with the corresponding residues in trypsin or chymotrypsin. If this degree of homology were to persist throughout the rest of the elastase sequence, then about half of the peptide chain would be identical with either chymotrypsin or trypsin. These homologies of sequence between the pancreatic serine proteinases have been discussed by Hartley et al. (1965), who concluded that they point to a common evolutionary ancestor of these different enzymes. No pair of these three enzymes seems to be significantly more closely related than another. Thus, in the regions illustrated in Table 7, 37 residues are identical between elastase and trypsin, 39 between elastase and chymotrypsinogen $A$, and 47 between chymotrypsinogen $A$ and trypsin. This point is illustrated in detail by examining the sequence between CyS194 and CyS-204, which surrounds the active-centre Ser-198. At position 195 methionine in chymotrypsin replaces glutamine in elastase or trypsin; at position 202 trypsin has valine rather than leucine; whereas at position 203 elastase is odd man out with histidine instead of valine. One might also suggest that if, as seems probable, all of these enzymes have a common catalytic site, none of the residues at positions 195, 202 or 203 can be mandatory for the catalytic activity.

The homologies are most striking in the $N$ terminal region (residues 16-21), the 'histidine loop' (residues 38-46 and 54-62) and in the large areas of sequence close to the $C$-terminus that form the 'serine knot' (residues 181-210 and 216-232). There is little homology around two half-cystine residues (residues 132-138 and 167-175), but it is reasonable to assume that these too will occupy the indicated positions along the peptide chain. If so, the primary structure of elastase can be illustrated as in Fig. 4, where bridge A indicates the 'histidine loop' (CyS-42

Table 6. Disulphide bridges of elastase

Bridge A: Trp-Ala-His-Thr-CyS-Gly-Gly-Thr-Leu<smiles>C1[As]C[AsH2]1</smiles>

Thr-Ala-Ala-His-CyS-Val-Asp-Arg-Glu

Bridge B: Ala-Ile-CyS-Ser-Ser-Ser-Ser-Ser-Tyr

Met-Val-CyS-Ala-Gly-Gly-Asp

Bridge D:

Ala- Asn - Asn -Ser - Pro-CyS-Tyr

Bridge C: Gly-Val-Arg-Ser-Gly-CyS-Gln-Gly-Asp-Ser-Gly-(Gly,Pro)-Leu-His-CyS-Leu-Val-Asn-Gln-Tyr

Val-Ser-Arg-Leu-Gly-CyS-Asn-Val-Thr-Arg-Lys-Pro-Thr-Val-Phe 


\section{Table 7. Sequence homologies in pancreatic proteinases}

E, Porcine elastase (this work); T, bovine trypsinogen (Walsh \& Neurath, 1964); CA, bovine chymotrypsinogen A (Hartley \& Kauffman, 1966); CB, bovine chymotrypsinogen B (Smillie \& Hartley, 1965). Identities of sequence are enclosed in boxes, chemical similarities are in bold type and differences between chymotrypsinogen $\mathbf{A}$ and chymotrypsinogen $B$ are in italics. The numbering is that of a hypothetical evolutionary precursor (Hartley et al. 1965).

\section{$\begin{array}{llllll}16 & 17 & 18 & 19 & 20 & 21\end{array}$ \\ E: Val Val-Gly-Gly Thr Glu \\ T: Ile -Val-Gly-Gly Tyr -Thr- \\ CA: Ile -Val Asn-Gly Glu Glu. \\ CB: Ile -Val Asn Gly Glu -Asp-}

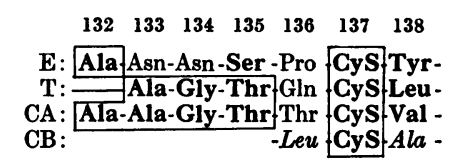

$\begin{array}{lllllllll}38 & 39 & 40 & 41 & 42 & 43 & 44 & 45 & 46\end{array}$ -Trp -Ala His Thr CyS-Gly-Gly Thr LeuGly-Tyr-His-Phe-CyS-Gly-Gly-Ser-LeuGly Phe-His-Phe-CyS-Gly-Gly-Ser-Leu His-Phe-CyS-Gly- Gly-Ser-Leu.

$\begin{array}{lllllllll}167 & 168 & 169 & 170 & 171 & 172 & 173 & 174 & 175\end{array}$ -Ala -Ile CyS-Ser Ser Ser -Ser -Ser -Tyr -Ser -Ser CyS-Lys -Ser Ala -Tyr -Pro -Gly -Thr-Asn CyS-Lys -Lys- Tyr - Trp -Gly -Thr -Thr-Asp CyS Arg- $\begin{array}{lllllllll}54 & 55 & 56 & 57 & 58 & 59 & 60 & 61 & 62\end{array}$ Thr-Ala-Ala-His -CyS-Val -Asp-Arg -Glu -Ser Ala -Ala-His -CyS-Tyr-Lys-Ser-Gly Thr-Ala-Ala-His -CyS Gly-Val-Thr-Thr Ala -Ala-His -CyS Gly -Val -Thr-Thr Met Val CyS-Ala -Gly - Gly -AspMet Phe CyS-Ala -Gly-Tyr-Leu-GluMet Ile CyS-Ala-Gly Ala -Ser Met Ile CyS-Ala-Gly.

$\begin{array}{lllllllllllllllllllll}189 & 190 & 191 & 192 & 193 & 194 & 195 & 196 & 197 & 198 & 199 & 200 & 201 & 202 & 203 & 204 & 205 & 206 & 207 & 208 & 209\end{array}$

$\begin{array}{ll}\text { E: } & \text { Gly-Val Arg-Ser-Gly GyS-Gln-Gly-Asp-Ser -Gly-(Gly, Pro)-Leu-His CyS-Leu -Val Asn-Gln -Tyr - } \\ \text { T: } & \text { Gly Gly -Lys-Asn-Ser-CyS-Gln-Gly-Asp-Ser -Gly-Gly-Pro -Val-Val-CyS-Ser - }\end{array}$

CA: Gly-Val Ser-Ser-GyS Met Gly-Asp-Ser-Gly- Gly-Pro -Leu-Val-CyS-Lys -Lys Asn-Gly Ala -

CB: Ser-CyS.Met Gly-Asp-Ser-Gly-Gly-Pro-Leu-Val-CyS Gln-Lys -

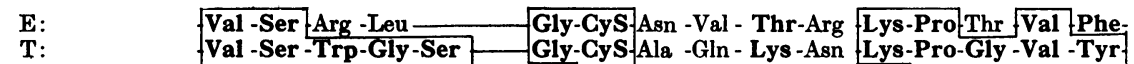

CA: $\quad$ Val -Ser-Trp-Gly-Ser Ser -Thr GyS-Ser -Thr-Ser -Thr I Pro-Gly -Val -Tyr

CB: CyS Ser -Thr-

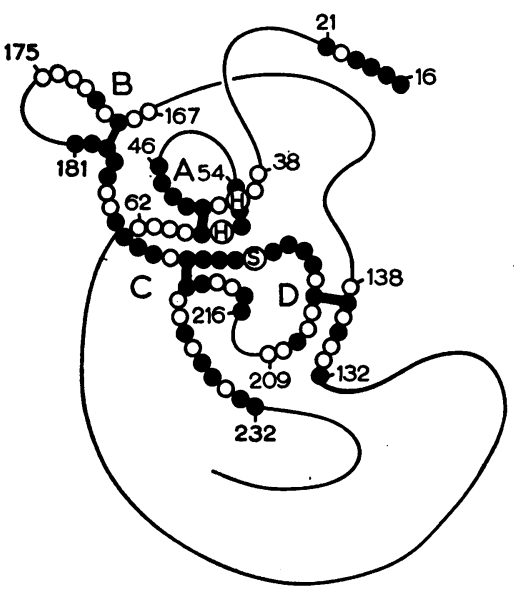

Fig. 4. Disulphide bridges in porcine elastase. The solid circles represent residues that are chemically similar or identical in either bovine trypsin or chymotrypsin. Residues are numbered as in Hartley et al. (1965). The histidine residues of the active centre are labelled $H$ and the activecentre serine residue is labelled $\mathrm{S}$.

to CyS-58), bridge $B$ is the 'methionine loop' (CyS-169 to CyS-183) and bridges $C$ and D form the 'serine knot' (CyS-194 to CyS-223 and CyS-204 to CyS-137).
Trypsin and chymotrypsin are enzymes where considerable differences in specificity seem to be grafted on to a common hydrolytic mechanism in which formation and hydrolysis of an acyl-Ser-198 intermediate are catalysed by a neighbouring histidine residue in the enzyme (reviewed by Bender \& Kézdy, 1965; Cunningham, 1965; Hartley, 1964). Preliminary studies with elastase (reviewed by Bender \& Kézdy, 1965) suggest that here too this common mechanism applies, though the specificity differs appreciably from that of either trypsin or chymotrypsin (Naughton \& Sanger, 1961). The inference that all these enzymes have common elements of tertiary structure is supported by examination of the homology around Ser-198 and His-57, which have both been identified as residues in the catalytic site, and by the similarity in the disulphide bridges. Bender, Killheffer \& Kézdy (1964) have observed that for a great range of nonpolar substrates the deacylation rates of trypsin and chymotrypsin are identical, implying common features in the structures of both enzymes that contribute to the specificity of the deacylation reaction and studies with competitive inhibitors have suggested that trypsin may have a 'hydrophobic slit' as part of its binding site, such as has been postulated for chymotrypsin (Inagami, 1964; Mares-Guia \& Shaw, 1965). All this suggests that the high degree of homology in the primary structure 
of these enzymes may, despite the differences in specificity, reflect very similar tertiary structures.

\section{REFERENCES}

Beaven, G. H. \& Holiday, E. R. (1952). Advanc. Protein Chem. 7, 319.

Bender, M. L. \& Kézdy, F. J. (1965). Annu. Rev. Biochem. 34, 49.

Bender, M. L., Killheffer, J. V. \& Kézdy, F. J. (1964). J. Amer. chem. Soc. 86, 5330.

Boulton, A. A. \& Bush, I. E. (1964). Biochem. J. 92 , $11 \mathrm{P}$.

Brown, J. R. \& Hartley, B. S. (1963). Biochem. J. 89, 59 P.

Brown, J. R. \& Hartley, B. S. (1966). Biochem. J. 101, 214.

Cunningham, L. W. (1965). In Comprehensive Biochemistry, vol. 16, p. 85. Ed. by Florkin, M. \& Stotz, E. H. Amsterdam: Elsevier Publishing Co.

Dent, C. E. (1947). Biochem.J.41, 240.

Fraenkel-Conrat, H., Harris, J. I. \& Levy, A. L. (1955). Meth. biochem. Anal. $2,383$.

Gray, W. R. \& Hartley, B. S. (1963a). Biochem J. 89, 59 P.

Gray, W. R. \& Hartley, B. S. (1963b). Biochem. J. 89, 379.
Hartley, B. S. (1964). In Structure and Activity of Enzymes, p. 47. Ed. by Goodwin, T. W., Harris, J. I. \& Hartley, B. S. London: Academic Press (Inc.) Ltd.

Hartley, B. S., Brown, J. R., Kauffman, D. L. \& Smillie, L. B. (1965). Nature, Lond., 207, 1157.

Hartley, B. S. \& Kauffman, D. L. (1966). Biochem. J. 101, 229.

Hartley, B. S., Naughton, M. A. \& Sanger, F. (1959). Biochim. biophys. Acta, 34, 243.

Hirs, C. H. W. (1956). J.biol.Chem. 219,611.

Inagami, T. (1964). J. biol. Chem. 239, 787.

Kauffman, D. L. (1965). J. molec. Biol.12,922.

Konigsberg, W. \& Hill, R. J. (1962). J. biol. Chem. 237, 2547.

Lewis, U. J., Williams, D. E. \& Brink, N. G. (1956). J. biol. Chem. 222, 705.

Mares-Guia, M. \& Shaw, E. (1965). J.biol. Chem. 240, 1579.

Naughton, M. A. \& Sanger, F. (1961). Biochem. J. 78, 156.

Naughton, M. A., Sanger, F., Hartley, B. S. \& Shaw, D. C. (1960). Biochem.J. T7, 149.

Sjöquist, J. (1960). Biochim. biophys. Acta, 41, 20.

Smillie, L. B. \& Hartley, B. S. (1964). J. molec. Biol. 10,183.

Smillie, L. B. \& Hartley, B. S. (1965). J. molec. Biol. 12, 933.

Smillie, L. B. \& Hartley, B. S. (1966). Biochem. J. 101, 232.

Smith, I. (1953). Nature, Lond., 171, 43.

Spackman, D. H. (1963). Fed. Proc. 22, 244.

Walsh, K. A. \& Neurath, H. (1964). Proc. nat. Acad. Sci., Wash., 52, 884. 